\title{
The Ptychanthoideae of Latin America: An Overview (Studies on Lejeuneaceae Subfamily Ptychanthoideae XVI)
}

\author{
S. Rob GRADSTEIN \\ Institute of Systematic Botany, Heidelberglaan 2, Utrecht, The Netherlands
}

\begin{abstract}
Recent taxonomic studies on the Lejeuneaceae subfamily Ptychanthoideae indicate that there are 59 species in 21 genera in Latin America. The ptychanthoid flora is very different from that of the Old World and has much fewer species but is slightly richer in endemic genera. About one third of the species are widespread neotropical elements, eleven species are transoceanicwide tropical, and the remaining species have more restricted distributions and belong to the endemic, Caribbean, Amazonian or Andean element. Data on sex distribution in the species indicate that bisexuality in Ptychanthoideae is much more common than previously assumed. The biogeography of the transoceanic species is briefly discussed.
\end{abstract}

The Lejeuneaceae subfamily Ptychanthoideae include about 170 species in 25 genera world-wide (Gradstein 1985a). They are primarily recognised by the seta, which is made up of 20 or more tiers of cells (usually 16 outer and 4 inner). In addition, Ptychanthoideae have a number of characteristics which are less constant or exclusive than the seta structure, e.g., 1) the relatively robust size of the plants and stems; stems with 10-75 rows of epidermal cells and a ventral merophyte of 4-16 cells across (except Dicranolejeunea and Acanthocoleus), 2) the frequent presence of brownish or blackish pigmentation and Frullania type branching, 3) entire underleaves ("holostipous"), 4) the hyaline papilla of the lobule apex, which is usually positioned on the inner surface of the lobule (by exception marginal in modified lobules), 5) the presence of bracteoles throughout the male spike (except in Neurolejeunea, Stictolejeunea and Symbiezidium), and 6) the frequent presence of pinguisane-type sesquiterpenes (Gradstein et al., in press).

Additional characters have been listed by Mizutani (1961, 1985), Gradstein (1975) and Schuster (1980) but most of these seem to be less relevant or incorrect. For instance, the fenestrate-type sporophyte capsules listed as a subfamily character by Mizutani and Gradstein are found only in the tribe Ptychantheae (van Slageren 1985) and are lacking in the Brachiolejeuneae, which have nodulose-type capsules as in members of the subfamily Lejeuneoideae. Schuster (in Longton \& Schuster 1983) estimated that about $85 \%$ of the species of Ptychanthoideae are dioicous and considered the high rate of unisexuality a character of the subfamily. However, among the 59 Latin American species currently recognised only 19 species (ca. $30 \%$ ) are strictly dioicous and the remaining species are monoicous or polyoicous. In 33 Australasian Ptychanthoideae probably only 6 species (18\%) are strictly dioicous (Thiers \& Gradstein, in press). Polyoicous species, which are made up of dioicous and monoicous populations, are fairly common in the Ptychanthoideae (e.g., in the genera Marchesinia, Frullanoides and Mastigolejeunea) and this phenomenon may be a reason why estimates of the percentage unisexuality in the species of Ptychanthoideae have been high in the past. The new figures indicate that data on sex distribution from the literature are often unreliable and that Ptychanthoideae and Lejeuneoideae probably do not differ in the percentages of monoicous (including polyoicous) and dioicous species.

The Ptychanthoideae as currently circumscribed include 59 species in Latin America. When compared with the last overview of the species of the area by Stephani (1898-1924: 193 species), the total number of species has decreased about $70 \%$. Eight new species have been detected in Latin America since Stephani's treatment. The figures are based on the results of taxonomic revisions of 15 out of 21 genera occurring in the area; the main genera for which revisions of the Latin American species are still lacking are Lopholejeunea, Mastigolejeunea and Neurolejeunea. When comparing the Latin American Ptychanthoideae with those of the Old World, it appears that there are about two times more species in the Old World (ca. 122 species). The number of Old World species may be somewhat inflated, however, because not all genera have been revised. Important Old World groups are Acrolejeunea, Caudalejeunea, Lopholejeunea, Mastigolejeunea, Schiffneriolejeunea and Thysananthus, which comprise about 100 species in the Old World and only 15 in Latin America. Latin America, however, is much richer in species of Brachiolejeunea, Bryop- 
TABLE 1. A classification of the genera of Lejeuneaceae subfam. Ptychanthoideae from Latin America. For a circumscription of the tribes and subtribes see Gradstein (1975) and Van Slageren (1985).

LEJEUNEACEAE subfam. PTYCHANTHOIDEAE Mizut.

(Syn.: Bryopteridaceae Stotl., Bryophyt. Biblioth. 3: 57, 1974; Lejeuneaceae subfam. Bryopteridoideae (Stotl.) Gradst., Bryophyt. Biblioth. 4: 139, 1975).

1. Tribus Ptychantheae Bischler

Subtribus Ptychanthinae Gradst.

Bryopteris complex: Bryopteris

Ptychanthus complex: Thysananthus, Mastigolejeunea, Schiffneriolejeunea

Acrolejeunea complex: Frullanoides, Acrolejeunea

Caudalejeunea complex: Caudalejeunea

Subtribus Archilejeuninae (Gradst.) Gradst. comb. nov. (Tribus Archilejeuneae Gradst., Bryophyt. Biblioth. 4: 146, 1975).

Archilejeunea complex: Spruceanthus, Archilejeunea, Verdoornianthus

Lopholejeunea complex: Marchesinia, Lopholejeunea

2. Tribus Brachiolejeuneae van Slag. \& Berendsen (in Kruijt \& Gradstein 1986: 306)

Brachiolejeunea complex: Brachiolejeunea, Blepharolejeunea, Acanthocoleus, Dicranolejeunea, Odontolejeunea, Lindigianthus

Symbiezidium complex: Symbiezidium

Stictolejeunea complex: Stictolejeunea, Neurolejeunea

teris and Frullanoides, which are represented in the Old World by only one species each. Moreover, Latin America has 5 endemic genera (Dicranolejeunea, Neurolejeunea, Blepharolejeunea, Lindigianthus, Verdoornianthus) whereas in the Old World there are 4 (Cephalolejeunea, Phaeolejeunea, Ptychanthus and Trocholejeunea). This brief comparison of the Old World and New World Ptychanthoideae floras indicates that the group has undergone a very different evolution in each of the two regions and suggests a long history of isolation from one another.

The classification of the genera of Latin American Ptychanthoideae is shown in Table 1. Contrary to my previous classification (Gradstein 1975), Bryopteris is included in the Ptychanthoideae, as advocated recently by Thiers (1985) and Mizutani (1985). Gametophytically, this genus is very similar to Ptychanthus and when sterile the two genera may easily be confused. The absence of leaf brace cells in Bryopteris can scarcely be taken as a major taxonomic character (Aphanolejeunea lacks brace cells too, see Thiers 1982), and a seta with more than 20 tiers of cells and a Frullania type sporeling, characteristic for Bryopteris (Stotler \& Crandall-Stotler 1974), are also found in Trocholejeunea sandvicensis. Van Slageren (1985) recently showed that Tro- choleieunea infuscata also has a seta of more than 20 rows of cells. I believe that the occurrence of a rather massive seta and sporeling in Bryopteris and Trocholejeunea is probably the result of parallel evolution within the Ptychanthoideae. It should also be realized that sporophytes have been examined thus far in only about $30 \%$ of the species and it may well be possible, therefore, that such deviating setas and sporelings do occur in other taxa of Ptychanthoideae as well. We certainly need more work on the morphology of the sporophyte of the Ptychanthoideae to arrive at a proper understanding of the variation of sporophytic characters within the subfamily.

\section{DISTRIBUTION}

The areas of distribution of the Latin American species of Ptychanthoideae fall into the following categories: endemic ( 7 species), Caribbean ( 5 species), Amazonian (10 species), Andean (7 species), widespread neotropical (19 species) and wide tropical (11 species). The endemic element includes three species which are thus far known from only one collection: Blepharolejeunea chimantaensis from the Chimantá table mountain in Venezuela (leg. Steyermark), Spruceanthus theobromae collected by Spruce around Guayaquil, Ecuador and Verdoornianthus griffinii which, surprisingly, is known only from the campus of the university of Manaus, Brazil (leg. D. Griffin) and has never been found elsewhere in Amazonia.

Other endemic species include Frullanoides laciniatiflora from Peru and Fr. mexicana known from a few localities in southern Mexico and northern Honduras. The latter species should be looked for elsewhere in Central America. At the infraspecific level several endemic taxa have been recognised as well and these include Frullanoides densifolia ssp. grandidentata (Clark) van Slag. from the Galapagos Islands, Stictolejeunea balfourii var. bekkeri Gradst. from the Guianas (Suriname, French Guiana (new)) and Symbiezidium transversale ssp. dentatum (Herz.) Gradst. \& van Beek from the Pacific coast of northern South America (Colombia, Ecuador). The latter subspecies is an example of a "Chocó element" (Gentry 1982). This element is very rich in endemic vascular plants, but among bryophytes only few endemic taxa are known; this may be due to poor knowledge of the bryoflora of the area. Other examples of Chocó elements in Lejeuneaceae seem to be Spruceanthus theobromae (to be re-collected!) and Luteolejeunea herzogii (Buchloh) Piippo (see Piippo 1986).

The Caribbean element includes species which occur preferably in coastal areas and may be tolerant 
of seasonal drought and salt spray (van Slageren 1985). Some of them are restricted to the islands of the West Indies (Frullanoides bahamensis, Neurolejeunea catenulata), others occur also on the mainland of Central and/or South America (Acanthocoleus juddii, Frullanoides corticalis, Lopholejeunea quelchii). Frullanoides corticalis is the most widely distributed species in this category and occurs also in the coastal areas of southeastern Brazil, possibly as the result of a long-range dispersal event (van Slageren 1985). Amazonian species include widespread taxa such as Archilejeunea fuscescens $(=A$. juliformis) and Acrolejeunea torulosa, occurring throughout the lowlands of northern South America east of the Andes, and taxa with more restricted distributions such as Archilejeunea porelloides and A. crispistipula and Verdoornianthus marsupiifolius, which are known only from the forests of inner Amazonia. Neurolejeunea seminervis and Schiffneriolejeunea amazonica are Amazonian species with a wide but rather scattered distribution. Only a few collections are available for each of them. In the Guianas these two species occur in the high canopy of the rain forest (unpublished observation) and I would therefore suspect that the inaccessibility of the habitat is a reason why so few records are known.

The Andean element includes species which are mainly distributed in the Andes of tropical South America. They may also occur in the mountains of Central America, however, and sometimes their ranges extend to Mt. Itatiaia and other mountains in southern Brazil and to the highest peaks of the Guayana Highlands and the West Indies. Examples are Thysananthus pterobryoides, Marchesinia robusta, and two species of Blepharolejeunea: B. incongrua and $B$. securifolia. Frullanoides densifolia and Brachiolejeunea laxifolia are the most widespread species in this category and they might also be included with the widespread neotropical element.

About half of the species of Ptychanthoideae occurring in Latin America are widespread. Some of them are transoceanic and occur also in palaeotropical regions, but the majority are purely neotropical. Wide tropical, transoceanic species include Acanthocoleus aberrans (=Dicranolejeunea aberrans), Acrolejeunea emergens, Brachiolejeunea phyllorhiza (=Dicranolejeunea phyllorhiza) (Fig. 1), Caudalejeunea lehmanniana, Frullanoides tristis (Fig. 2), Lopholejeunea subfusca and L. muelleriana, Mastigolejeunea auriculata, Odontolejeunea lunulata, Schiffneriolejeunea polycarpa (Fig. 3) and Stictolejeunea balfourii (Fig. 4). Prior to recent monographic work, all of them were known from the various continents under different names except for Stictolejeunea balfourii, which was newly discov- ered in tropical America in 1981 (Gradstein 1985a). This interesting species grows on roots etc. (occasionally epiphyllous) close to the ground in the understory of the moist primary rainforest, usually very sheltered and in very humid environments (e.g., near streamlets). I would predict therefore, that further collections of $S$. balfourii will turn up when careful searching is done in the habitats where it occurs.

The transoceanic ranges of the Ptychanthoideae and other tropical bryophytes have been the subject of several recent papers(e.g., Grolle 1969; Pócs 1976; Frahm 1982; Gradstein et al. 1983; Reese 1987). Possible explanations of the ranges usually focus on step-by-step overland dispersal prior to the separation of the land masses in the late Mesozoic, or on long-range dispersal. Usually arguments pro and contra can be given for each of the two explanations and the question as to which of the two causes is responsible usually cannot be answered with certainty (although for genera continental drift is often taken as the explanation and for species long-range dispersal (except for very ancient species)).

In the case of the transoceanic species of the Ptychanthoideae, the following data are relevant (list not exhaustive):

1. All transoceanic species have bisexual spores. This fact lends support to the long-distance dispersal hypothesis.

2. Some transoceanic species (Acrolejeunea emergens, Frullanoides tristis, Schiffneriolejeunea polycarpa, see Figs. 1-4) have a tricentric distribution pattern (South America, Africa, India/Himalayas) found also in mesozoic conifers of the Glossopteris flora. This fact lends support to a Gondwanalandic origin of the species and subsequent step-by-step overland dispersal (e.g., Fulford 1963).

3. The occurrence of fossil Stictolejeunea cf. squamata in Dominican amber (Gradstein msc.) indicates that this species is possibly more than 20 million years old. Other ptychanthoid species very similar to present-day species have been found in Baltic amber, aged 32 million years (Grolle 1987). The available evidence indicates that speciation in Ptychanthoideae and other liverworts may have been slow in the last 32 million years and that some species may be millions of years old. Whether these old species already existed at the time of the separation of the landmasses in the late Mesozoic cannot be concluded on the basis of this evidence, however.

4. Van Zanten and Gradstein (in press) recently examined the feasibility of long-range dispersal, based on a testing of drought, frost and UV resistance of spores and sporelings as well as on other evidence, in 86 tropical liverwort species including the following Ptychanthoids: Blepharolejeunea incongrua, B. securifolia, Brachiolejeunea laxifolia, 

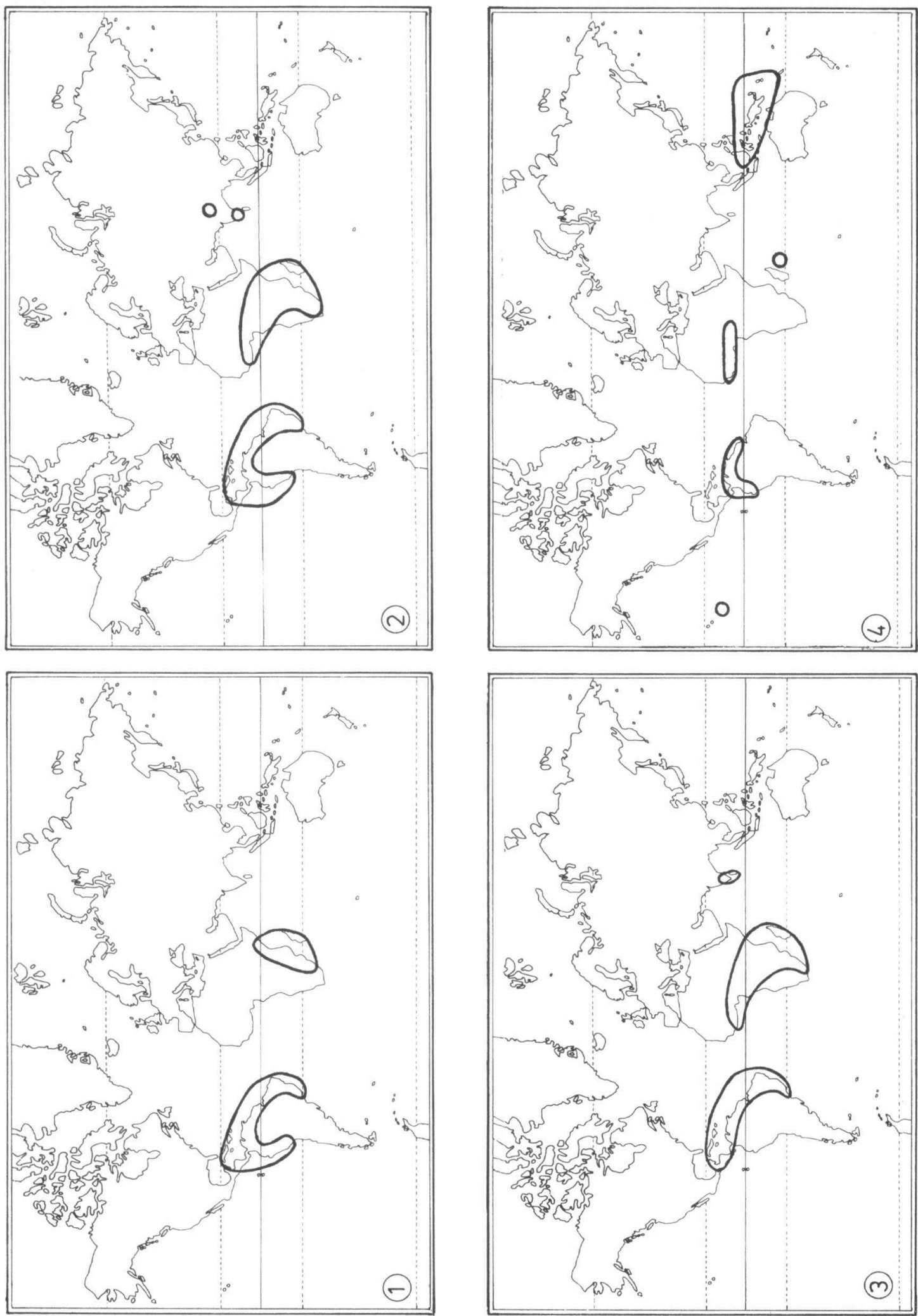
Dicranolejeunea axillaris, Frullanoides densifolia and Marchesinia brachiata (all "endemic" to Latin America); Brachiolejeunea phyllorhiza and Stictolejeunea balfourii (transoceanic). In the endemic Latin American species drought resistance of spores and sporelings varied from less than one day (a few hours?) in Blepharolejeunea incongrua and B. securifolia, a few days (less than five) in Brachiolejeunea laxifolia to 2(-3) weeks in Dicranolejeunea axillaris, Frullanoides densifolia and Marchesinia brachiata. These data indicate a poor dispersibility in the two species of Blepharolejeunea and in Brachiolejeunea laxifolia, and a moderately good capacity for dispersal in the three other neotropical species tested. Excellent spore and sporeling viability of up to two months was found in the AfroAmerican Brachiolejeunea phyllorhiza (Fig. 1) and this supports the hypothesis that this species might have attained its transoceanic range via long-range air dispersal. In the pantropical Stictolejeunea balfourii (Fig. 4), however, drought and frost resistance is very poor (less than a day, possibly less than a few hours) and this would preclude the effectiveness of long-range dispersal in this species. As the species grows in very sheltered locations in dense understories of natural, primary forests (see above), where dispersal can hardly be very effective, it may be argued that this species attained its vast range via step-by-step dispersal over ancient land connections rather than via long-range dispersal. Such a reasoning would indicate that the species is at least 90 million years old.

5. A basic problem in the biogeography of transoceanic species is the question whether such species are indeed "good" biological species. Disjunct populations may be morphologically and anatomically identical, yet different at the genetic and chemical level. Using electrophoretic analysis of isoenzymes, Odrzykoski (1987) demonstrated the existence in the widespread Conocephalum conicum of five different genetic strains which can be interpreted as sibling species. Electrophoresis and other genetic and chemical techniques can be expected to become more widely applied in bryology in future years and this may lead to the discovery of sibling species in transoceanic ptychanthoids, especially among those with poor dispersal capacities.

The few data presented here are meant to illustrate the kind of (scanty) evidence available for biogeographic interpretations in Lejeuneaceae. Some progress has clearly been made in recent times and the results may suggest directions into which future work should go.

\section{List OF THE GeNera AND SPECIES OF Ptychanthoideae of Latin America}

\section{Acanthocoleus Schust.}

Ref.: Kruijt, in preparation

A. aberrans (Lindenb. \& Gott.) Kruijt-widespread in tropical America. Also in Africa

A. juddii Kruijt-northern West Indies, Mexico

Acrolejeunea (Spruce) Schiffn.

Ref.: Gradstein 1975

A. emergens (Mitt.) Steph. - Central and tropical South America. Also in Africa and Asia (Sri Lanka)

A. heterophylla (Evans) Grolle \& Gradst. -Central America, Florida

A. torulosa (Lehm. \& Lindenb.) Schiffn.-Central and tropical South America

Archilejeunea (Spruce) Schiffn.

Ref.: Gradstein and Buskes 1985.

A. auberiana (Mont.) Evans 1)-widespread in tropical America

A. crispistipula (Spruce) Steph.-inner Amazonia

A. fuscescens (Hampe ex Lehm.) Fulf. 2)-northern South America, Costa Rica

A. parviflora (Nees) Schiffn.- widespread in tropical America. Also in Africa?

A. porelloides (Spruce) Schiffn.-inner Amazonia

Blepharolejeunea S. Arn.

Ref.: van Slageren and Kruijt 1985

B. chimantaensis van Slag. \& Kruijt-Guayana Highlands (Venezuela)

B. fuegiana (Besch. \& Mass.) Gradst. - Tierra del Fuego

B. incongrua (Lindenb. \& Gott.) van Slag. \& Kruijt-Central America, tropical Andes

B. saccata (Steph.) van Slag. \& Kruijt-tropical America (scattered)

B. securifolia (Steph.) Schust. - northern Andes, S.E. Brazil

Brachiolejeunea (Spruce) Schiffn.

Ref.: van Slageren 1985; Kruijt and Gradstein 1986

B. fernandeziana S. Arn. - Juan Fernandez Is.

B. laxifolia (Tayl.) Schiffn. - widespread in tropical America

B. leiboldiana (Got. \& Lindenb.) Schiffn. - tropical America (scattered)

B. phyllorhiza (Nees) Kruijt \& Gradst. - widespread in tropical America. Also in Africa (Fig. 1)

B. spruceana (Mass.) Schiffn.-southern South America

Bryopteris (Nees) Lindenb.

Ref.: Stotler and Crandall-Stotler 1974 3)

B. diffusa (Sw.) Nees-widespread in tropical America

B. filicina (Sw.) Nees-widespread in tropical America

B. flaccida Lindenb. \& Hampe-Central America

Caudalejeunea (Spruce) Schiffn.

Ref.: Schuster 1980

C. lehmanniana (Gott.) Evans-widespread in tropical America. Also in West Africa

Figures 1-4. Transoceanic species in the Ptychanthoideae. - 1. Brachiolejeunea phyllorhiza. - 2. Frullanoides tristis. - 3. Schiffneriolejeunea polycarpa. - 4. Stictolejeunea balfourii. 
Dicranolejeunea (Spruce) Schiffn.

Ref.: Kruijt, in preparation

D. axillaris (Nees \& Mont.) Schiffn. - Central and tropical South America

Frullanoides Raddi

Ref.: van Slageren 1985

$F$. bahamensis (Evans) van Slag. - northern West Indies, Florida

$F$. corticalis (Lehm. \& Lindenb.) van Slag. - coastal tropical America, especially West Indies

$F$. densifolia Raddi-Central and South America

$F$. laciniatiflora (Loitl.) van Slag. - Andes of Peru

$F$. liebmanniana (Lindenb. \& Gott.) van Slag. - tropical America (scattered)

$F$. mexicana van Slag. - southern Mexico, Honduras

$F$. tristis (Steph.) van Slag. - widespread in tropical America. Also in Africa and Asia (India, Nepal) (Fig. 2)

Lindigianthus Kruijt \& Gradst.

Ref.: Kruijt and Gradstein 1985

L. cipaconeus (Gott.) Kruijt \& Gradst.-northern Andes, Costa Rica

Lopholejeunea (Spruce) Schiffn.

Ref.: Evans 1907; Schuster 1980; Gradstein msc.

L. quelchii Steph. (= L. howei Evans syn. nov.)-West Indies, Guianas

L. muelleriana (Gott.) Schiffn.-widespread in tropical America. Also in Australia (Thiers \& Gradstein, in press) and ? Africa (VandenBerghen 1984)

L. subfusca (Nees) Schiffn. - widespread in tropical America. Also in Africa, Asia and Australasia

Marchesinia S. Gray

Ref.: Geissler, in preparation

$M$. bongardiana (Lehm. \& Lindenb.) Trevis. - widespread in tropical America

$M$. brachiata (Sw.) Schiffn. - widespread in tropical America

M. robusta (Mitt.) Schiffn.-tropical Andes, Central America

Mastigolejeunea (Spruce) Schiffn.

Ref.: Spruce 1884; Schuster 1980

$M$. auriculata (Wils.) Schiffn. 4)-widespread in tropical

America. Also in Africa and Asia (Gradstein \& Inoue

1980; Thiers \& Gradstein, in press)

M. plicatiflora (Spruce) Steph.-Amazonia

Neurolejeunea (Spruce) Schiffn.

Ref.: Evans 1907; Schuster 1980

$N$. breutelii (Gott.) Evans - widespread in tropical America

$N$. catenulata (Nees) Schiffn. - Puerto Rico, Jamaica

$N$. seminervis (Spruce) Schiffn.-Amazonia, Guianas

Odontolejeunea (Spruce) Schiffn.

Ref.: Teeuwen, in preparation

$O$. decemdentata (Spruce) Steph.-northern South America, Central America, West Indies

O. lunulata (Web.) Schiffn.- - widespread in tropical America. Also in Africa

O. rhomalea (Spruce) Steph. - northern South America, Central America

Schiffneriolejeunea Verd.

Ref.: Gradstein 1974, 1985a

S. amazonica Gradst. -Amazonia, Guianas

$S$. polycarpa (Nees) Gradst. - widespread in tropical America. Also in Africa and Asia (Sri Lanka, India) (Fig. 3)

Spruceanthus Verd.
S. theobromae (Spruce) Gradst. - Ecuador

Stictolejeunea (Spruce) Schiffn.

Ref:: Gradstein 1985b

S. balfourii (Mitt.) E. W. Jones-tropical South America (scattered). Also in Africa, Asia and Australasia (Fig. 4)

S. squamata (Willd.) Schiffn.-widespread in tropical America

Symbiezidium Trevis.

Ref.: Gradstein and van Beek 1985

S. barbiflorum (Lindenb. \& Gott.) Evans-widespread in tropical America

S. transversale (Sw.) Trevis.-widespread in tropical America

Thysananthus Lindenb.

Ref.: Fulford 1941 5)

T. amazonicus (Spruce) Schiffn.-Amazonia, Guianas, Trinidad, Cuba

T. evansii Fulf. - Belize

T. pterobryoides (Spruce) Schiffn. - northern Andes, Central America

Verdoornianthus Gradst.

Ref.: Gradstein 1978

V. griffinii Gradst._inner Amazonia (Manaus)

V. marsupiifolius (Spruce) Gradst. -inner Amazonia

\section{Notes}

1) Gradstein and Buskes (1985) treated $A$. auberiana (Mont.) Evans as a variety of $A$. parviflora (Nees) Schiffn. (A. parviflora var. florentissima (Spruce) Schiffn.). Recently, I was able to collect material of $A$. auberiana and $A$. parviflora in the field (French Guiana, Suriname) and to study the habitats of the two taxa. It appears that $A$. parviflora always occurs in sheltered, moist locations, usually in the understory of the rain forest, whereas $A$. auberiana grows in more exposed, drier habitats: in the rain forest canopy, at forest edges or on isolated trees, and on shrubs in savannas. The very different ecologies of the two taxa coupled with their different morphologies (lobule) are a reason to accept the two taxa as species rather than varieties.

2) Gradstein and Buskes (1985) accepted the name $A$. juliformis (Nees) Gradst. but Dr. R. Grolle (oral communication) has kindly drawn my attention to the fact that the basionym of $A$. juliformis should be Phragmicoma juliformis Nees 1845 rather than Jungermannia juliformis Nees 1833 , as the latter name was (mis)spelled $J$. "filifor$m i s$ " in the original publication. It follows that $A$. juliformis (Nees) Gradst. is antedated by $A$. fuscescens (Hampe ex Lehm.) Fulf. (basionym: Lejeunea fuscescens Hampe ex Lehm. 1838) which should be accepted as the correct name.

3) Stotler and Crandall-Stotler (1974) recognised three further species of Bryopteris in tropical America: $B$. fruticulosa Tayl., B. liebmanniana Lindenb. \& Gott. and $B$. trinitensis (Lehm. \& Lindenb.) Lehm. \& Lindenb. These are closely related to $B$. filicina and often difficult to separate from the latter.

4) $M$. innovans (Spruce) Steph. is probably a synonym of $M$. auriculata.

5) The record of $T$. comosus Lindenb. from tropical America (see Fulford 1941) needs confirmation.

\section{ACKNOWLEDGEMENT}

I began my work on the Ptychanthoideae in 1970/1971 at the University of Cincinnati, where I was a research 
"Manual of the leafy Hepaticae of Latin America" project (NSF grant GB 7139 to Dr. Fulford). This paper is dedicated to Dr. Fulford in recognition of her outstanding scholarship and in grateful remembrance of her stimulus and support as a teacher.

\section{Literature Cited}

Evans, A. W. 1907. Hepaticae of Puerto Rico 7. Stictolejeunea, Neurolejeunea, Omphalanthus and Lopholejeunea. Bulletin of the Torrey Botanical Club 34: 134.

FraHM, J. P. 1982. Grossdisjunktionen in Artarealen sudamerikanischer und afrikanischer Campylus-Arten. Lindbergia 8: 45-52.

Fulford, M. H. 1941. Studies on American Hepaticae I. Revision of the genus Thysananthus. Bulletin of the Torrey Botanical Club 68: 32-42.

- 1963. Continental drift and distribution patterns of the leafy Hepaticae, pp. 140-145. In Polar Wandering and Continental Drift. Society of Economic Palaeontologists and Mineralogists, Special Paper 1D.

Gentry, A. H. 1982. Phytogeographic patterns as evidence for a Choco refuge, pp. 112-136. In G. T. Prance (ed.), Biological Diversification in the Tropics. Plenum Press, New York.

Gradstein, S. R. 1974. Studies on Lejeuneaceae subfam. Ptychanthoideae I. Nomenclature and taxonomy of Ptychocoleus, Acrolejeunea and Schiffneriolejeunea. Journal of the Hattori Botanical Laboratory 38: 327336.

- 1975. A taxonomic monograph of the genus $A C$ rolejeunea (Studies on Lejeuneaceae subfam. Ptychanthoideae III). Bryophytorum Bibliotheca 4: 1-162.

- 1978. Studies on Lejeuneaceae subfam. Ptychanthoideae IV. Verdoornianthus, a new genus from Amazonas, Brazil. THE BRYOLOGIST 80: 606-61 1.

- 1985a. A guide to the holostipous Lejeuneaceae. Beiheft zur Nova Hedwigia 80: 13-29.

- 1985b. A revision of the genus Stictolejeunea (Spruce) Schiffn. (Studies on Lejeuneaceae subfam. Ptychanthoideae XIV). Beiheft zur Nova Hedwigia 80: 195-220.

nomic significance of secondary metabolites in the Lejeuneaceae (Hepaticae). Journal of the Hattori Botanical Laboratory (in press).

- \& J. VAN BEEK. 1985. A revision of the genus Symbiezidium Trevis. (Studies on Lejeuneaceae subfam. Ptychanthoideae XV). Beiheft zur Nova Hedwigia 80: 221-248.

\& C. M. C. Buskes. 1985. A revision of neotropical Archilejeunea (Spruce) Schiffn. (Studies on Lejeuneaceae subfam. Ptychanthoideae IX). Beiheft zur Nova Hedwigia 80: 89-112.

- \& H. INoue. 1980. Studies on Lejeuneaceae subfam. Ptychanthoideae V. A review of the species of Ceylon. Bulletin of the National Science Museum, Tokyo, Ser. B (Bot.), 6: 23-32.

- T. Pocs \& J. VANA. 1983. Disjunct Hepaticae in tropical America and Africa. Acta Botanica Hungarica 29: 127-171.

Grolle, R. 1969. Grossdisjunktionen in Artarealen Lateinamerikanischer Lebermoose, pp. 562-582. In E. J. Fittkau et al. (eds.), Biogeography and Ecology in South America, Vol. 2. Junk, The Hague.

- 1987. Hepatics in amber-What do they tell on evolution?, p. 266. Abstracts, XIV International Botanical Congress, Berlin.
KRUIJT, R. CH. 1985. A preliminary revision of the genus Dicranolejeunea (Spruce) Schiffn. (Studies on Lejeuneaceae subfam. Ptychanthoideae XI). Beiheft zur Nova Hedwigia 80: 155-163.

\& S. R. Gradstein. 1985. A new genus of Lejeuneaceae from tropical America: Lindigianthus gen. nov. (Studies on Lejeuneaceae subfam. Ptychanthoideae XII). Beiheft zur Nova Hedwigia 80: 165-172.

$-\&-1986$. Studies on Lejeuneaceae subfam. Ptychanthoideae X. On Brachiolejeunea phyllorhiza (Nees) Kruijt \& Gradstein comb. nov. (Hepaticae). Nova Hedwigia 43: 299-309.

Longton, R. \& R. M. Schuster. 1983. Reproductive biology of bryophytes, pp. 386-462. In R. M. Schuster (ed.), New Manual of Bryology, Vol. 1. The Hattori Botanical Laboratory, Nichinan.

Mizutani, M. 1961. A revision of Japanese Lejeuneaceae. Journal of the Hattori Botanical Laboratory 24: 115-302.

- 1985. Subfamilies of Lejeuneaceae. Proceedings of the Bryological Society of Japan 4: 3-4.

OdrzYkoski, I. J. 1987. Phylogeny of Conocephalum conicum species group (Hepaticae), based on molecular data, p. 267. Abstracts, XIV International Botanical Congress, Berlin.

PIIPPO, S. 1986. A monograph of the genera Lepidolejeunea and Luteolejeunea (Lejeuneaceae, Hepaticae). Acta Botanica Fennica 132: 1-69.

Pócs, T. 1976. Correlations between the tropical African and Asian bryofloras, I. Journal of the Hattori Botanical Laboratory 41: 95-106.

ReESE, W. D. 1987. Calymperes (Musci: Calymperaceae): World ranges, implications for patterns of historical dispersion and speciation, and comments on phylogeny. Brittonia 39: 225-237.

SCHUSTER, R. M. 1980. The Hepaticae and Anthocerotae of North America, Vol. IV. Columbia University Press, New York.

Slageren, M. W. VAN. 1985. A taxonomic monograph of the genera Brachiolejeunea and Frullanoides (Hepaticae). Mededelingen van het Botanisch Museum en Herbarium van de Rijksuniversiteit Utrecht 544: 1309.

\& R. CH. KRUIt. 1985. A review of the genus Blepharolejeunea S. Arn. Beiheft zur Nova Hedwigia 80: 113-154.

SPRUCE, R. 1884. Hepaticae Amazonicae et Andinae. Jubuleae. Transactions and Proceedings of the Botanical Society Edinburgh 15: 1-308.

StePHANI, F. 1898-1924. Species Hepaticarum, Vols. IVI. Geneva.

Stotler, R. \& B. Crandall-Stotler. 1974. A monograph of the genus Bryopteris. Bryophytorum Bibliotheca 3: 1-159.

ThIERS, B. 1982. Branching in the Lejeuneaceae I: A comparison of branch development in Aphanolejeunea and Cololejeunea. THE BRYoLoGIST 85: 104-109.

- 1985. Branching in Lejeuneaceae III: Ptychanthoideae. Beiheft zur Nova Hedwigia 80: 31-61.

\& S. R. GradsteIN. Lejeuneaceae of Australia. I. Subfamily Ptychanthoideae. Memoirs of the New York Botanical Garden (in press).

VANDENBERGHEN, C. 1984. Le genre Lopholejeunea (Spruce) Schiffn. (Lejeuneaceae, Hepaticae) en Afrique. Bulletin du Jardin Botanique Belgique 54: 393464.

ZANTEN, B. O. VAN \& S. R. GRADSTEIN. Experimental dispersal geography of neotropical liverworts. Beiheft zur Nova Hedwigia (in press). 